\title{
Globalization: Ecological Consequences of Global-Scale Connectivity in People, Resources, and Information
}

\author{
Debra P.C. Peters \\ Jornada Basin Long Term Ecological Research Program and \\ U.S. Department of Agriculture - Agricultural Research Service, Las Cruces, New Mexico \\ USA
}

\section{Introduction}

Globalization is a phenomenon affecting all facets of the Earth System. Within the context of ecological systems, it is becoming increasingly apparent that global connectivity among terrestrial systems, the atmosphere, and oceans is driving many ecological dynamics at finer scales and pushing thresholds of change (Fagre et al., 2009; MEA, 2005; Rial et al., 2004). For example, increasing atmospheric $\mathrm{CO}_{2}$ and other greenhouse gases are increasing temperature and modifying precipitation regimes with short- and long-term impacts on ecological systems (IPCC, 2007). Changes in climate also have secondary effects by influencing disturbance regimes, such as changing the intensity of North American hurricanes that link to rainfall patterns in Africa (Emanual, 2005; Trenberth, 2005). Climate also interacts with terrestrial systems to alter wildfire regimes and to connect large areas within a continent as well as connecting locations globally through particulates in the atmosphere (Allen 2007; Dale et al., 2001; Kitzberger et al., 2007). Massive dust storms driven by hot and dry weather interacting with human activities can connect continents, such as dust storms in Asia that deposit dust particles in North America (Jaffe et al., 2003). Glacier melt in polar regions is increasing sea level globally with consequences for nearshore and inland ecosystems (Hopkinson et al., 2008). Movement of humans through improved transportation is leading to spread of pests and pathogens with ecological consequences for agricultural crops (Perrings et al., 2010). Long-distance movement of invasive plants and animals is often facilitated by human activities (Crowl et al., 2008).

In addition, fine-scale ecological dynamics can propagate spatially to influence broad spatial extents with feedbacks to global drivers (Peters et al., 2004a). Dust storms in Asia are initiated as cultivated marginal lands in dry years that become connected by wind and water. Erosion and deposition of soil, nutrients, and dust particles occur locally, but also propagate to regions and continents (Field et al., 2010). As the dry conditions continue, large dust storms can develop with transport of materials eventually to North America. Similar intra- and inter-continental dynamics have been observed historically with the Dust Bowl in the central U.S. (Peters et al., 2006a), in the southwestern US (Neff et al., 2008), and in Antarctica (McConnell et al., 2007), and are occurring in the deserts of Africa and Asia to contribute to most of the global mineral aerosol load (Tanaka \& Chiba, 2006). 
Because global change drivers, including climate, landuse, and movement of the biota, as well as ecosystem dynamics are changing nonlinearly through time for many locations, it is critical that connections across different aspects of the Earth System be examined to improve both understanding and prediction of future ecological dynamics (Peters et al., 2008). A better understanding is needed about these various drivers, how they are changing in response to globalization, and what are the consequences to ecological dynamics and ecosystem services globally. This chapter addresses two objectives. The first objective is to describe three classes of events that emerge from a common, integrated framework; each class has different characteristics that connect ecological systems at fine to broad scales with consequences for globalization. Examples are provided to illustrate how various global change drivers can influence and interact with heterogeneity in land surface properties of vegetation and soil pattern to either synchronize, attenuate or amplify impacts of drivers on ecological systems. The second objective is to describe approaches to deal with global change impacts when locations may be connected at multiple scales.

\section{Integrated framework to link local to global scales}

Recently, a conceptual framework was developed to understand and predict broad-scale ecosystem dynamics. This framework is based on connectivity in material and information flow that links multiple scales of observation, from local sites within landscapes to regions and continents (Peters et al., 2008). The basic premise of the framework is that both the climate system and human activities operate across multiple spatial and temporal scales to influence and be influenced by ecological systems (Fig. 1). The term "driver" refers to atmospheric or Earth-surface processes and human activities that affect ecological systems. This definition allows for interactions among drivers as well as feedback mechanisms between drivers and responses.

Patterns in drivers occur across a range of scales. For example, the drivers influencing rainfall and temperature occur mainly at three scales: (1) global circulation patterns, which influence long-term climatic averages, (2) subcontinental to continental-scale phenomena driven by patterns such as the El Niño-Southern Oscillation (ENSO), and (3) meso-scale patterns as weather interacting with local and regional topography. Other drivers also exhibit multi-scale patterns, such as connectivity within and among major river systems that leads to variable patterns in land use, human settlement, invasive species, and nutrient distribution. Although human activities occur at multiple scales, local scale impacts increasingly drive ecosystem dynamics and land change at broader, regional scales (Luck et al., 2001, Dietz et al., 2007). Interactions among climate, human populations, and disturbance agents have both ecological and socio-economic consequences (Yates et al., 2002).

Thus, connectivity across scales results from broad-scale drivers (climate and people) interacting with finer-scale patterns and processes that redistribute materials within and among linked terrestrial and aquatic systems (Fig. 1) (Peters et al., 2008). Climate and human activities interact with patterns and processes at multiple, finer scales (blue arrows). These drivers can influence broad-scale patterns directly, and these constraints may act to overwhelm heterogeneity and processes at meso-scales, and at fine scales of local sites. Broad-scale drivers can also impact broad-scale patterns indirectly through their interactions with disturbances, including the spread of invasive species or fire. Connectivity via the 
transfer of materials occurs both at the meso-scale and at fine scales within sites where terrestrial and aquatic systems are connected. Transport vectors (e.g., wind, water, animals, people) move materials and resources (e.g., dust, soil, water, energy, nutrients, propagules, diseases, chemical constituents) within and among terrestrial and aquatic systems across a range of spatial and temporal scales (Fig. 1 red arrows). Changes in the drivers and patternprocess relationships through time and across space can alter ecosystem dynamics within particular locations (Fig 1; black arrows), and can change dynamics across locations and large regions (Allen, 2007).

\section{Classes of driver impacts on ecological dynamics}

Although this framework shares some similarities with hierarchical systems where broadscale drivers constrain fine-scale patterns, and fine-scale patterns provide the mechanistic understanding for broad-scale patterns (Allen \& Starr, 1982), the focus here is understanding and predicting the conditions when broad-scale drivers overwhelm finescale variability, and the conditions when fine-scale processes propagate nonlinearly to influence broad spatial extents. I define and illustrate three classes of events that connect ecological systems globally, and can be explained using this overarching framework. These cases differ in: (1) initial properties of the driver, (2) change in ecological response, and (3) the explanatory variables for the response. These differences are summarized in Table 1, and detailed below.

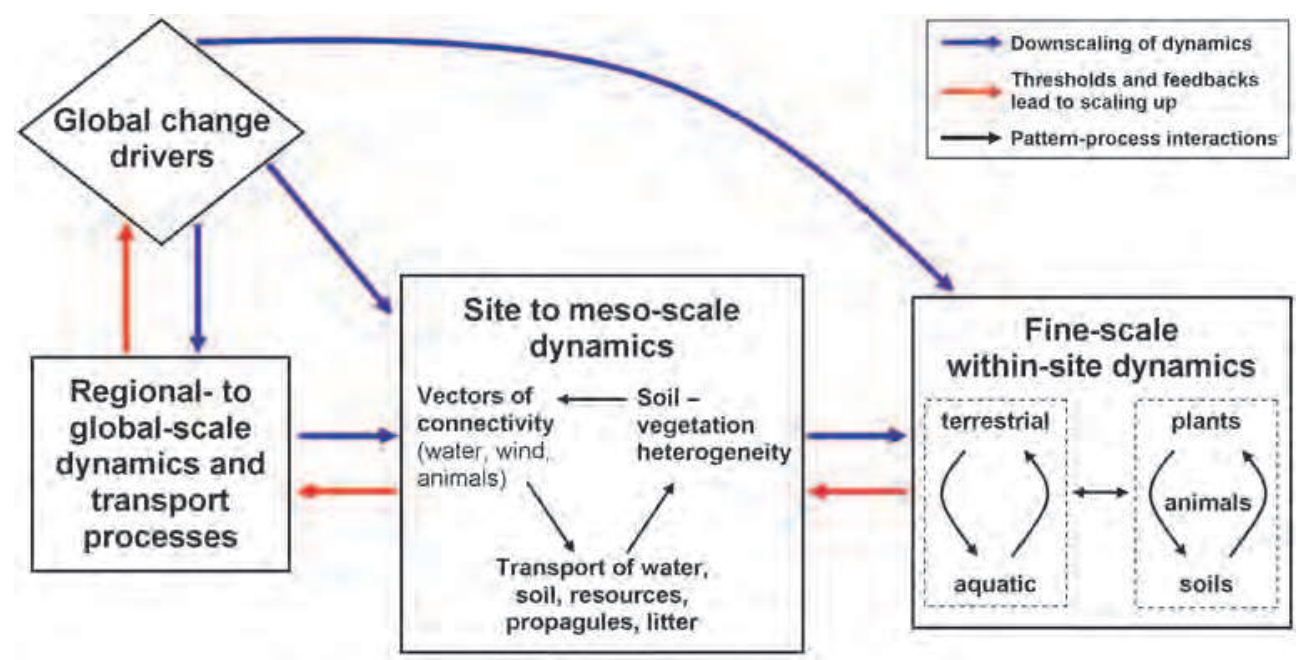

Fig. 1. Conceptual framework to link spatial and temporal scales to result in continentalscale patterns and dynamics leading to globalization with consequences to ecological dynamics at finer scales. Both downscaling of global change drivers to finer scales (blue arrows) and upscaling of ecological dynamics to regional and continental scales (red arrows) are shown. Adapted from Peters et al. (2008). 


\begin{tabular}{|c|c|c|c|c|c|c|}
\hline \multirow[t]{2}{*}{ Class of event } & \multicolumn{3}{|c|}{ Initial conditions of driver } & \multirow[t]{2}{*}{$\begin{array}{c}\text { Spatial } \\
\text { extent of } \\
\text { ecological } \\
\text { impact } \\
\text { through time }\end{array}$} & \multicolumn{2}{|c|}{$\begin{array}{l}\text { Explanatory variables for } \\
\text { magnitude of ecological } \\
\text { impact }\end{array}$} \\
\hline & Intensity & $\begin{array}{c}\text { Spatial } \\
\text { extent }\end{array}$ & Duration & & Initially & Through time \\
\hline Synchronization & Low & $\begin{array}{l}\text { Meso- } \\
\text { to } \\
\text { global } \\
\text { scale }\end{array}$ & $\begin{array}{l}\text { Years to } \\
\text { decades }\end{array}$ & $\begin{array}{l}\text { No } \\
\text { directional } \\
\text { change: } \\
\text { varies with } \\
\text { driver and } \\
\text { event }\end{array}$ & $\begin{array}{l}\text { Driver } \\
\text { intensity }\end{array}$ & $\begin{array}{l}\text { Driver } \\
\text { intensity }\end{array}$ \\
\hline Attenuation & Very high & $\begin{array}{l}\text { Local- } \\
\text { to } \\
\text { meso- } \\
\text { scale }\end{array}$ & $\begin{array}{l}\text { Sub-daily } \\
\text { to } \\
\text { months }\end{array}$ & $\begin{array}{l}\text { Rapid } \\
\text { increase } \\
\text { followed by } \\
\text { gradual } \\
\text { asymptote }\end{array}$ & $\begin{array}{l}\text { Physical } \\
\text { properties of } \\
\text { event } \\
\text { - Initial driver } \\
\text { intensity } \\
\text { - Distance to } \\
\text { impacted } \\
\text { system at } \\
\text { onset }\end{array}$ & $\begin{array}{l}\text { Physical } \\
\text { properties of } \\
\text { event } \\
\text { Ecological } \\
\text { properties }\end{array}$ \\
\hline Amplification & $\begin{array}{l}\text { Low to } \\
\text { moderate }\end{array}$ & Local & $\begin{array}{l}\text { Sub-daily } \\
\text { to } \\
\text { decades }\end{array}$ & $\begin{array}{l}\text { Increases } \\
\text { non-linearly } \\
\text { with } \\
\text { thresholds }\end{array}$ & $\begin{array}{l}\text { Ecological } \\
\text { processes and } \\
\text { properties } \\
\text { (dominant } \\
\text { processes } \\
\text { change } \\
\text { through time } \\
\text { and space) }\end{array}$ & $\begin{array}{l}\text { Ecological } \\
\text { processes and } \\
\text { properties } \\
\text { Spatial extent of } \\
\text { impact } \\
\text { increases } \\
\text { through time } \\
\text { Land- } \\
\text { atmosphere } \\
\text { feedbacks }\end{array}$ \\
\hline
\end{tabular}

Table 1. Three classes of globalization events determined by ecological responses that result from interactions between drivers and ecosystems.

\subsection{Synchronization of ecological responses across scales}

The first case occurs when a driver of low intensity over a large spatial extent for a long period of time overwhelms fine-scale heterogeneity in landscape structure of vegetation, soils, topography, and degree of urbanization (Fig. 2). These drivers, also called press disturbances (Bender et al., 1984), can occur for years to decades or centuries. Impacts of the event tend to be related to the intensity or magnitude of the driver. The less well-known or appreciated feature of this class of events is that the driver acts to synchronize ecological dynamics over a large spatial extent. An example is provided by global circulation patterns interacting with sub-continental to continental-scale phenomena to generate regional to continental-scale drought. The most intense, widespread, long-term drought in recent US history occurred in the 1930s (Fig. 3). Long-term climate data combined with average on-site 
conditions have been used to characterize this drought within the longer-term record using the Palmer Drought Severity Index (PDSI). The PDSI is calculated based on precipitation and temperature data, as well as the local Available Water Content (AWC) of the soil (Palmer, 1965). Data starting in 1895 for nine locations from different ecosystems and locations across the US show the variability in PDSI through time (Fig. 3) (data from http://www.cpc.ncep.noaa.gov/; excerpted from Peters et al., 2011). Although all locations had at least one drought year (negative PDSI), the extended sequence of dry years was more pronounced in the western and central parts of the country. It is expected that this synchronicity in climate drivers had large impacts on ecosystem dynamics over the same time period, although comparable multi-site data across the country for this historical period do not exist. However, it is known that synchronicity in ecosystem dynamics occurred at the regional scale during this drought. A number of research sites were monitored for vegetation change in the central Great Plains during the 1930s, and the results showed high losses in grass recovery throughout the region (Albertson \& Weaver, 1942; Weaver \& Albertson, 1940). Recent studies show that plant production can be synchronized at the landscape scale during long-term drought, but these same locations act independent from each other during individual dry or wet years as well as during a period of multiple wet years (Peters et al., submitted). These results suggest that broad-scale drivers can have different influences on connectivity and ecological dynamics depending on changes in magnitude and duration of the driver.

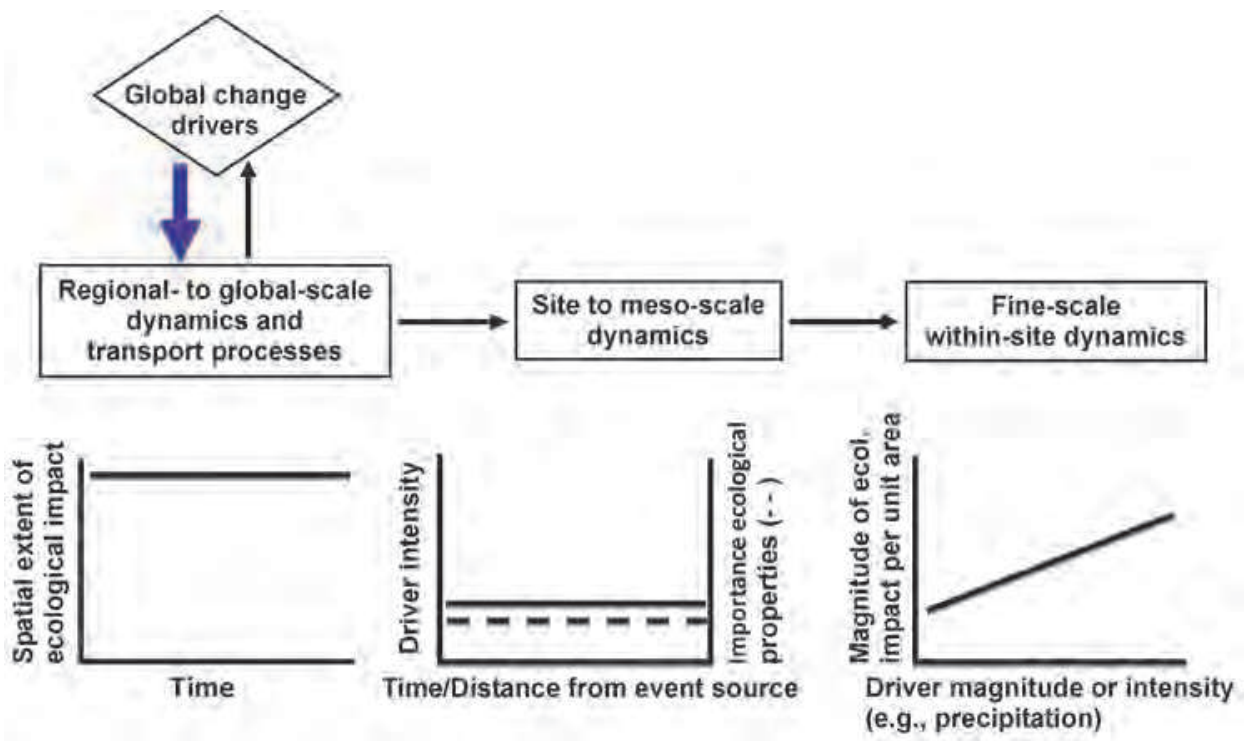

Fig. 2. Synchronization occurs when a driver of low intensity over a large spatial extent for a long period of time (thick blue line) overwhelms fine-scale heterogeneity in landscape structure of vegetation, soils, topography, and degree of urbanization to result in similar impacts. These drivers, also called press disturbances, can occur for years to decades or centuries. Impacts of the event tend to be linearly related to the intensity or magnitude of the driver. Driver intensity and importance of ecological properties are not related to the time since the event or distance from the event source. 
Other examples of spatial synchronization in magnitude of drivers include higher human population density in the eastern US causing higher total sulfur dioxide and nitrogen oxide emissions compared to the West (Driscoll et al., 2011). Emissions of sulfur dioxide are the result of coal-fired electric utilities in the east (Dennis et al., 2007). Emissions of nitrogen oxides result from electric utilities and transportation sources in the east whereas ammonia emissions are higher in the west due to agricultural activities (Driscoll et al., 2003). These patterns in emissions are reflected in continental-scale patterns in atmospheric deposition. For example, nitrogen in precipitation is higher in the east compared to the northwest (Fig. $4 a, b)$. The largest decreases in atmospheric deposition of nitrogen in the past several decades has occurred in the east (Fig. 4c, d) as a result of the Clean Air Act and greater reductions in fossil fuel emissions at that broad scale (Peters et al., 2011). Studies of effects of broad-scale synchronicity in deposition of nutrients limiting to plants and animals are needed to determine if ecological responses are also synchronized or if they are dependent on fine-scale heterogeneity in other drivers and ecological patterns and processes.
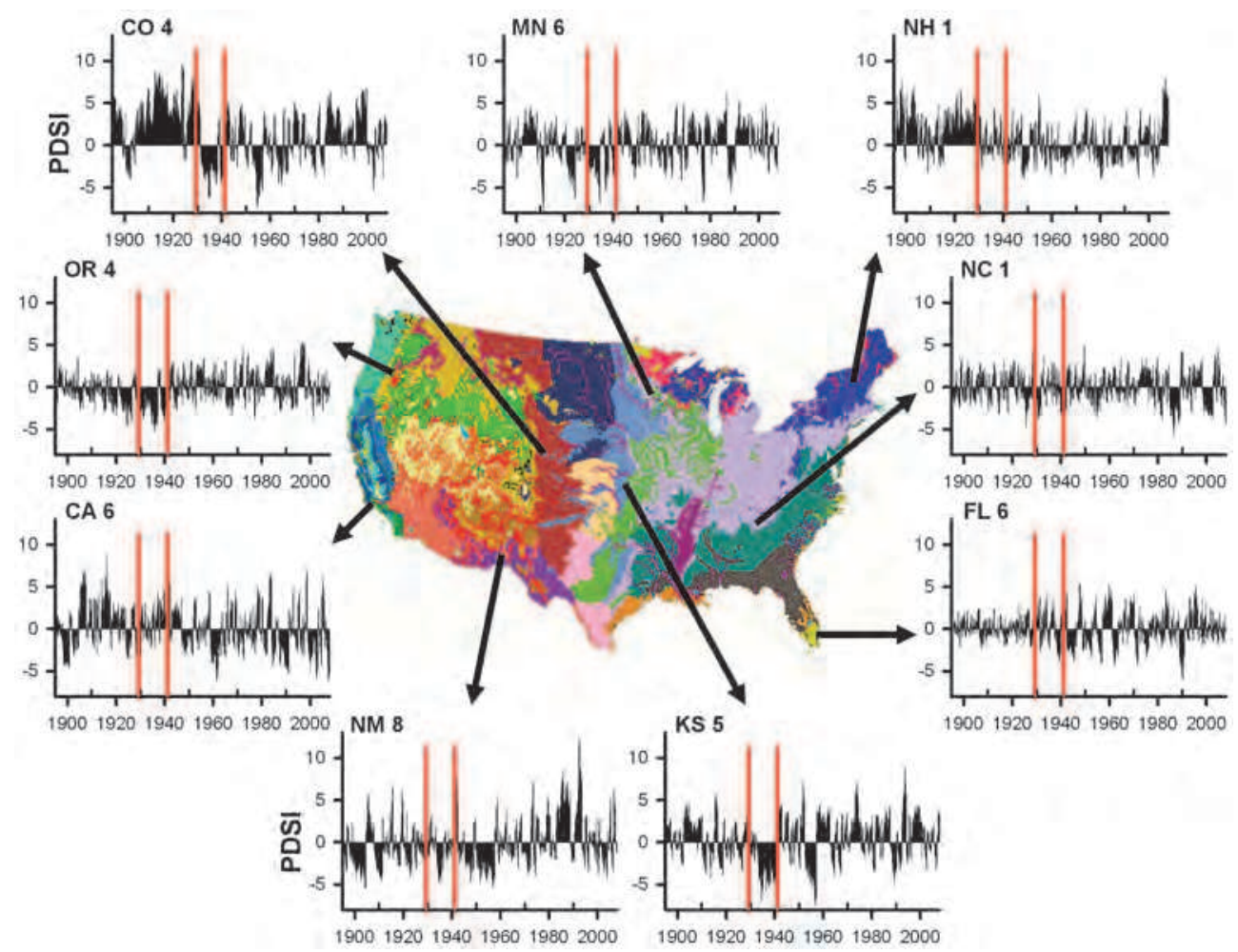

Fig. 3. Palmer Drought Severity Index (PDSI) through time from 1895 to 2008 for nine sites selected to cover the continental US and to represent major ecosystem types (background colors). Synchronicity in climate drivers across the West (excluding California) and Midwest is shown by negative values during the drought of the 1930s (between red lines). 
Concentration of nitrogen (nitrate) in precipitation (mean)

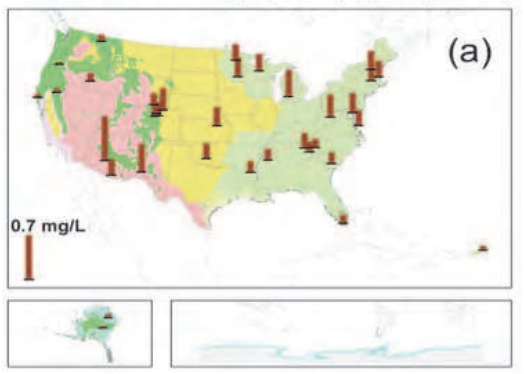

Concentration of nitrogen (nitrate) in precipitation (slope)

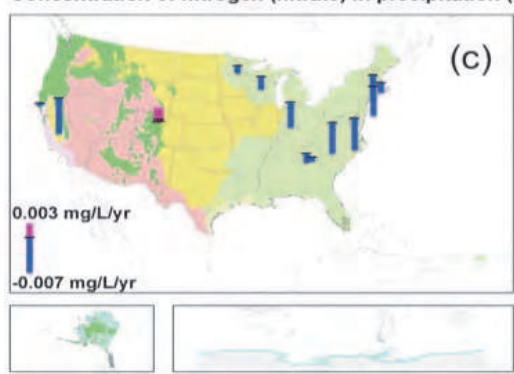

Deposition of nitrogen (nitrate) from precipitation (mean)

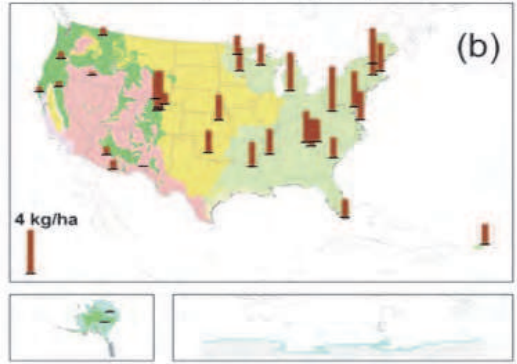

Deposition of nitrogen (nitrate) from precipitation (slope)

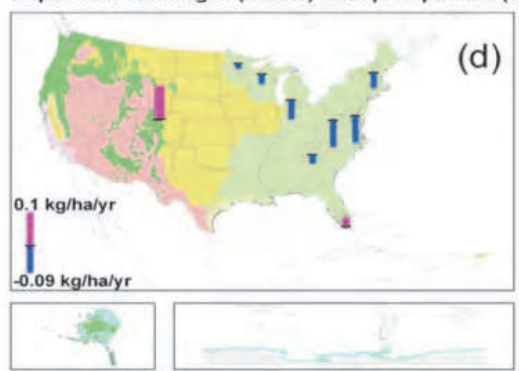

Fig. 4. Atmospheric deposition of nitrogen in precipitation as (a) and (c) volume weighted concentration $(\mathrm{mg} / \mathrm{L})$ and $(\mathrm{b})$ and $(\mathrm{d})$ wet deposition $(\mathrm{kg} / \mathrm{ha})$. Top panels are long-term averages. Bottom panels are slopes of regressions through time where positive values are pink and negative values are blue. Original data from http:/ / nadp.sws.uiuc.edu/. Synthesized data from http:/ / www.ecotrends.info. Figure from Peters et al. (2011).

\subsection{Attenuation of ecological responses across scales}

The second case occurs when a very high intensity driver occurs over a relatively short time period (days to weeks) to initially impact a large area (Fig. 5). Through time, these broadscale "pulse" events (Bender et al., 1984) can propagate globally. However, the rate of spread slows down and dissipates over time with an attenuation in intensity of impacts. Fine-scale heterogeneity in landscape structure becomes increasingly important to the ecological response as the intensity of the driver decreases in time and space. The interaction between a driver and fine-scale ecological and transport processes results in no relationship between driver intensity or magnitude and ecological impact.

Examples of broad-scale pulses that propagate spatially, but lose intensity include tsunamis and volcanoes. In both examples, a high intensity event occurs within short time period of days to weeks over a fairly large area that then propagates spatially, often to impact global systems. The tsunami in December 2004 resulted from a 9.0 magnitude earthquake that influenced a large area under the Indian Ocean (Fig. 6a). An extremely high intensity wave and the following successive waves were spread globally within 44 hours (Fig. 6b). The rate of spread decreased through time and space (Merrifield et al., 2005) such that the severity of impact was negatively related to distance from the source of the event. Closer locations to the earthquake were devastated by the impact of the wave regardless of land- or seascape structure. As distance from the source increased, impact decreased and structures in the 
form of vegetation, buildings, marshes, forests, and geologic formations were more effective at minimizing the impact to both ecological and human-dominated systems (Fernando \& McCulley, 2005). Similarly, the Icelandic volcano of 2010 spewed an ash cloud over much of the Northern Hemisphere within several weeks (Fig. 6c). This dense cloud closed European air space and affected air travel globally. Ecological effects of volcanic eruptions can be indirect as a result of interactions across scales. For example, sulfur dioxide in the ash from the 1991 eruption of Mount Pinatubo in the Philippines combined with water vapor in the upper atmosphere to reflect sunlight back to the atmosphere, and decrease in air surface temperatures globally 0.4 to $0.5^{\circ} \mathrm{C}$ for several years. Effects of multi-year temperature decreases and atmospheric inputs to ecological systems are unknown and not wellrecognized as to their potential importance because these are rare events. However, the propagation of these impacts and their high intensity with pulses of material inputs need to be examined within the broader context of global change drivers interacting across scales.

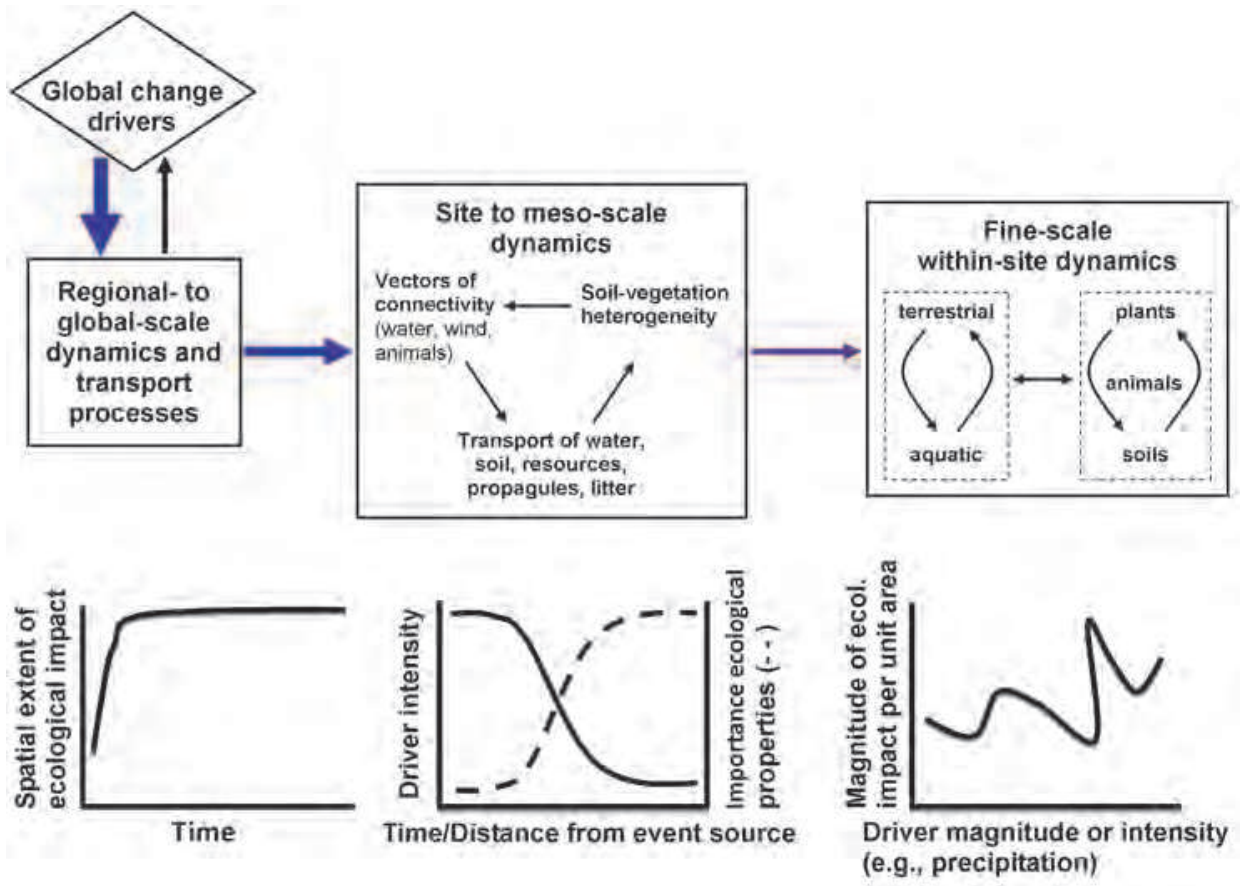

Fig. 5. Attenuation occurs when a very high intensity driver occurs over a relatively short time period (days to weeks) over a large area (thick blue line). Through time, these broad-scale "pulse" events dissipate and attenuate spatially. Fine-scale heterogeneity in landscape structure becomes increasingly important to the ecological response as the intensity of the driver decreases in time and space. Magnitude of impact is not linearly related to driver characteristics.

\subsection{Amplification of ecological responses across scales}

In the third case, low intensity drivers over a small spatial extent interact with properties of the ecological system to modify pattern-process relationships through time and space (Fig. 
7). The result is that ecological responses propagate non-linearly to affect a broad spatial extent as a result of transport processes at multiple scales. The dominant process changes through time to result in threshold dynamics and qualitatively different kinds and rates of change than were involved in the initial interaction (Peters et al., 2004a). The rate of propagation of fine-scale changes to broader spatial scales depends on the spatial configuration, connectivity, and flows within and among fine- to meso-scale units, the interaction of these patterns with broad-scale drivers, and feedbacks among these elements across scales (Okin et al., 2009). The thresholds indicate that distinct exogenous processes or endogenous positive feedbacks are governing rates of change. This framework based on spatial nonlinearities complements antecedent concepts about the rate and spatial pattern of change by relating fine-scale processes to drivers and feedbacks at broader extents.

(a)

(b)

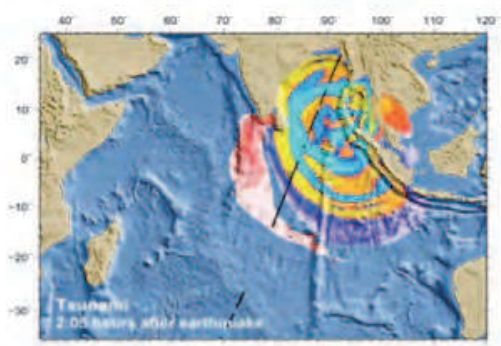

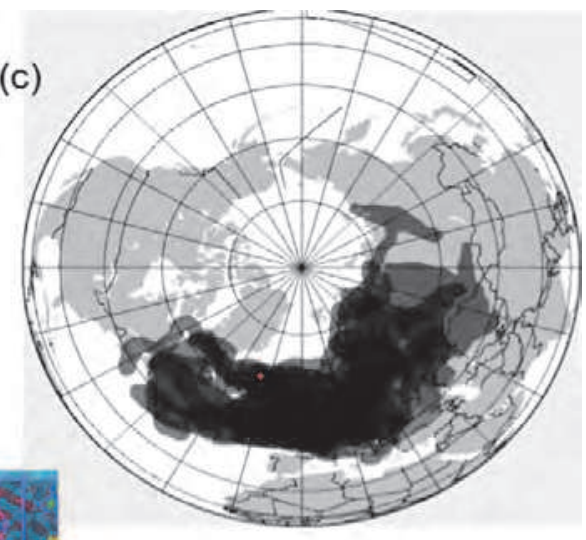

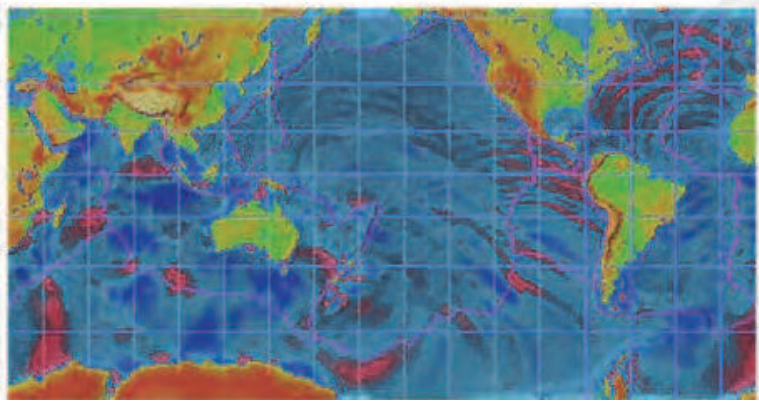

Fig. 6. (a) Tsunami in 2004 in the Indian Ocean began as 9.0 magnitude earthquake that (b) propagated globally within 44 hours (darker oceanic colors indicate greater intensity). As the intensity dissipated, the ecological and societal impacts decreased. Initial spread was governed by physical processes whereas impact through time became increasingly influenced by landscape structure and biotic processes. Images from National Oceanic and Atmospheric Administration (http:/ / noaa.gov). (c) Icelandic volcano in 2010 exhibited high intensity dynamics followed by global transmission and dissipation of intensity and energy through time and space "(darker colors indicate greater intensity). Based on maps found at http://www.metoffice.gov.uk/ aviation/vaac/vaacu). Daily layers from 14-25 April 2010 combined into one image. 
Examples of this behavior that can emerge across scales include wildfire that starts with a single ignition source, often from lightning or human causes, and cascades to influence large landscapes (e.g., Fig. 8a; Yellowstone National Park). Large fires often generate their own weather that leads to multiple ignition sources with inputs to the atmosphere that connects broad spatial extents (Fig. 8b). Nonlinear spread of invasive species across continents, water and sediment redistribution from small river channels to the ocean, and desertification dynamics from small, isolated patches to inter-continental transport of dust are additional dynamics that follow this model (Allen, 2007; Crowl et al., 2008; Marshall et al., 2008; Peters et al., 2006b; Williamson et al., 2008).

These cross-scale interactions can result in surprising behavior that cannot be predicted based on historical drivers or local inputs. For example, small thunderstorms in northwestern Africa can develop through time into hurricanes that influence North America after passing through a series of storm stages with increasing intensity and spatial extent (Fig. 9) (Dunn, 1940; Goldenberg et al., 2001; Landsea, 1993). Some African thunderstorms move off-shore to create tropical depressions in the Atlantic Ocean (Avila \& Clark 1989). Of these, some develop into tropical storms and some storms build into sufficient intensity and extent to develop into hurricanes that strike the coast of North America. Each stage is controlled by a different set of physical-atmospheric-chemical processes, including teleconnections between storms in Africa and the El Niño Southern Oscillation in the tropical Pacific (Glantz et al., 1991). A shift to a new stage results in the crossing of a threshold and fundamental change in the behavior of the storm (Landsea et al., 1998), similar to wildfire and other cascading events (Fig. 9a). Furthermore, each storm is influenced by the atmospheric conditions at the time such that each follows its own storm track. Most hurricanes follow a landfall track similar to Hurricane Hugo (Fig. 9a), although the band of landfall can stretch to central Texas. However, in rare cases, a hurricane can hit land in extreme southern Texas and move to the northwest before heading eastward (Fig. 9b). For example, Hurricane Dolly in 2008 created extremely wet summer conditions as far inland as the Chihuahuan deserts of North America with $86 \%$ of the total annual rainfall falling in July (Fig. 9c). This surprising amount of rainfall initiated perennial grass recruitment events with legacy effects to the present (Peters et al., submitted). Although Hurricane Dolly did not start in western Africa, future hurricanes that connect deserts in North America with northwestern Africa under climate change are under-appreciated, yet may provide explanations for extreme system behavior and opportunities for future regime shifts or the development of novel ecosystems (Hobbs et al., 2006).

\section{Approaches to understanding and prediction of connected systems}

As evidence mounts that ecological systems are becoming increasingly connected through the transport of materials, resources, and information by a variety of transport vectors (animals, wind, water, disturbance), the challenges associated with understanding and predicting these complex dynamics are also increasing. Because errors of commission increase with the number of measurements, transport of materials from adjacent and nonadjacent locations should first be examined for importance relative to local inputs (Peters et al., 2004b). If redistribution across locations is important to ecological dynamics, then there are four main approaches to measuring or sampling both local inputs and fluxes or flows through time across a defined spatial extent: (1) Cross-location comparisons of existing data can provide important insights into patterns in driver and response data that may be 


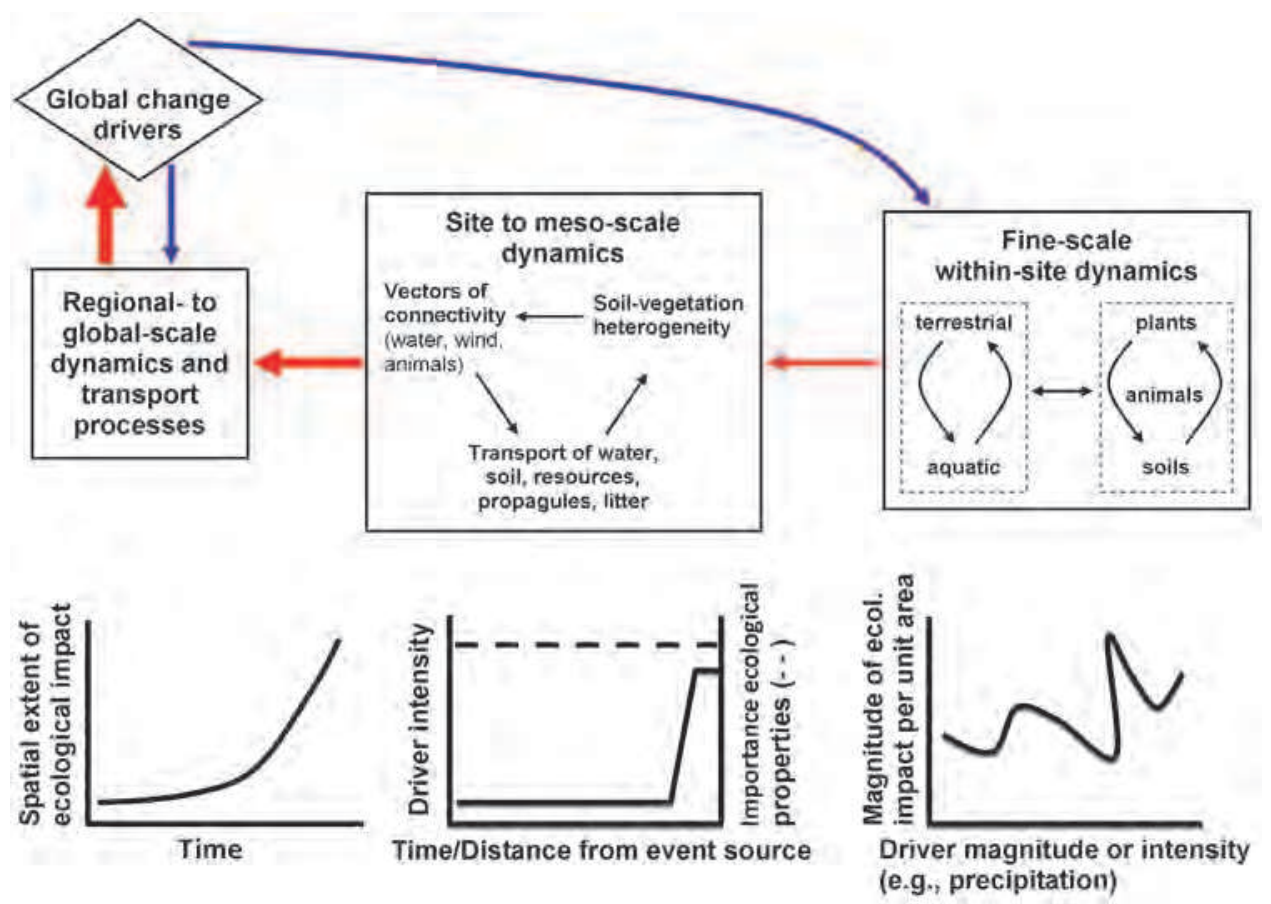

Fig. 7. Amplification occurs when low intensity drivers interact with properties of the ecological system, in particular transport processes at multiple, interacting scales, to modify pattern-process relationships through time and space (Peters et al., 2004a) The result is that ecological responses propagate non-linearly to affect a broad spatial extent (increasingly thicker red arrows). Driver intensity is low until land-atmosphere interactions become the dominant process that feed back to fine-scale patterns and processes. These feedbacks amplify the influence of the driver.

synchronized across locations (e.g., Figs. 3, 4). Analyses can also be used to determine if responses at one location are correlated with drivers or responses at another location as an indicator of synchronicity. Recently, hundreds of long-term data sets from 50 sites in the US were examined in this screening approach to determine both broad-scale patterns in drivers and responses, and potential connectivity among locations (Peters, 2010; Peters et al., 2011); (2) Experimental manipulations can be used to examine the role of similar events of a driver in different systems across a range of scales. Most experiments to-date are short-term $(<5$ years) and have focused on local inputs rather than the horizontal transport of materials (e.g., Fay et al., 2008; Heisler-White et al., 2009). Notable exceptions are experiments that modify vegetation structure in order to alter resource redistribution (Jones \& Post, 2004; Li et al., 2009a, 2009b) and tracer experiments used in streams (Mulholland et al., 2008; O'Brien et al., 2007); (3) Simulation models can be used to compare dynamics within and among ecosystem types to a variety of drivers, and to tease apart the relative importance of local inputs and transport of materials. Most ecosystems models simulate local climate inputs, although fire spread models, wind erosion, and hydrologic models examine the importance of transport to ecological dynamics (Daly et al., 20001; Ivanov et al., 2008; Okin, 2008); (4) 
One of the most promising approaches is provided by network-level observatories that collect similar types of measurements in similar ways (Peters, 2010). In the US, these national-level networks include sites operated by the USDA Forest Service and Agricultural Research Service, and the Long Term Ecological Research Program (Peters et al., 2011). Multi-site comparisons of historic data have proven to be very insightful (Lugo et al., 2006; Moran et al., 2008), and have led to the development of emerging networks with standardized data protocols across diverse ecosystems (e.g., the National Ecological Observatory Network). Comparable standardization in cyberinfrastructure is being developed to promote data and metadata protocols for archival and retrieval that are necessary for open data access and multi-site comparisons globally (Reichman et al., 2011).
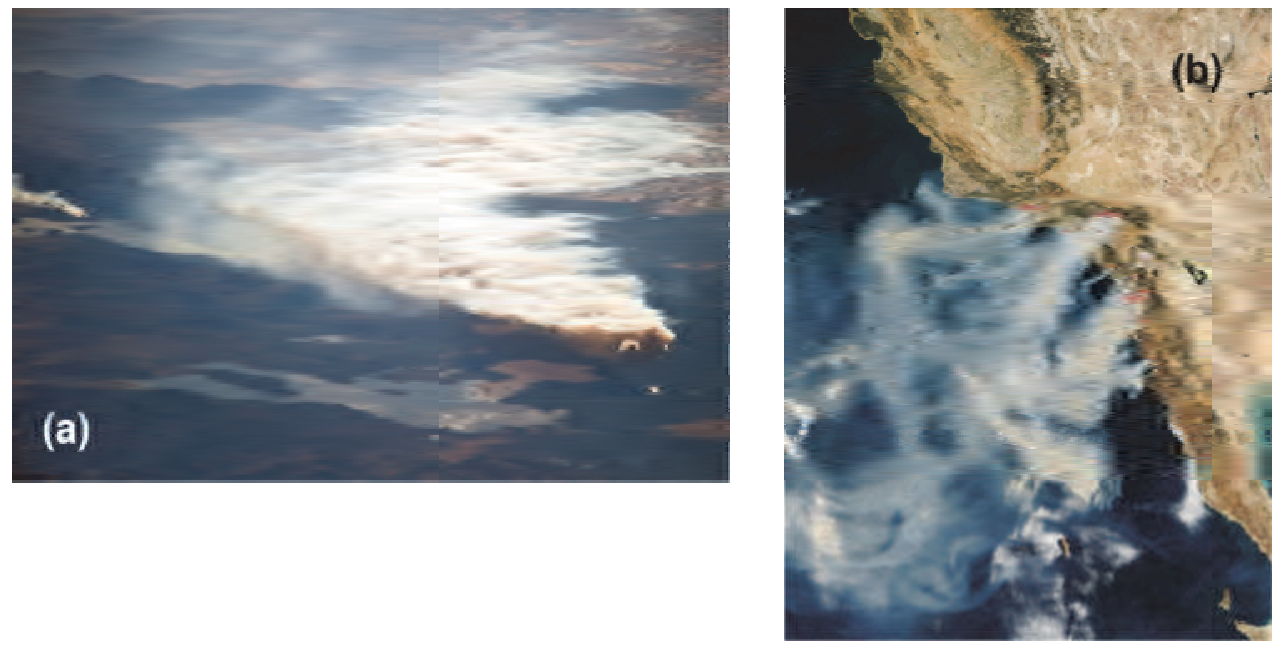

Fig. 8. (a) Small ignition sources (e.g., a lightning strike) can initiate a wildfire that spreads nonlinearly to influence very large landscapes (Allen, 2007). The 2009 fire in Yellowstone National Park started by lightning on 13 September grew to 9300 ha by 1 October. Photo taken from the International Space Station looking southwest towards Teton Range showing Yellowstone Lake in center with reflection of smoke plume (http:/ / earthobservatory.nasa.gov). (b) Multiple ignition sources are common as fires increase in size regionally with large smoke and particulate plumes released to the atmosphere to connect region, continents, and the globe. Fires in southern California in October 2003 were fueled by hot, dry winds: at least one fire grew 10,000 acres in just 6 hours (http:/ / earthobservatory.nasa.gov). 

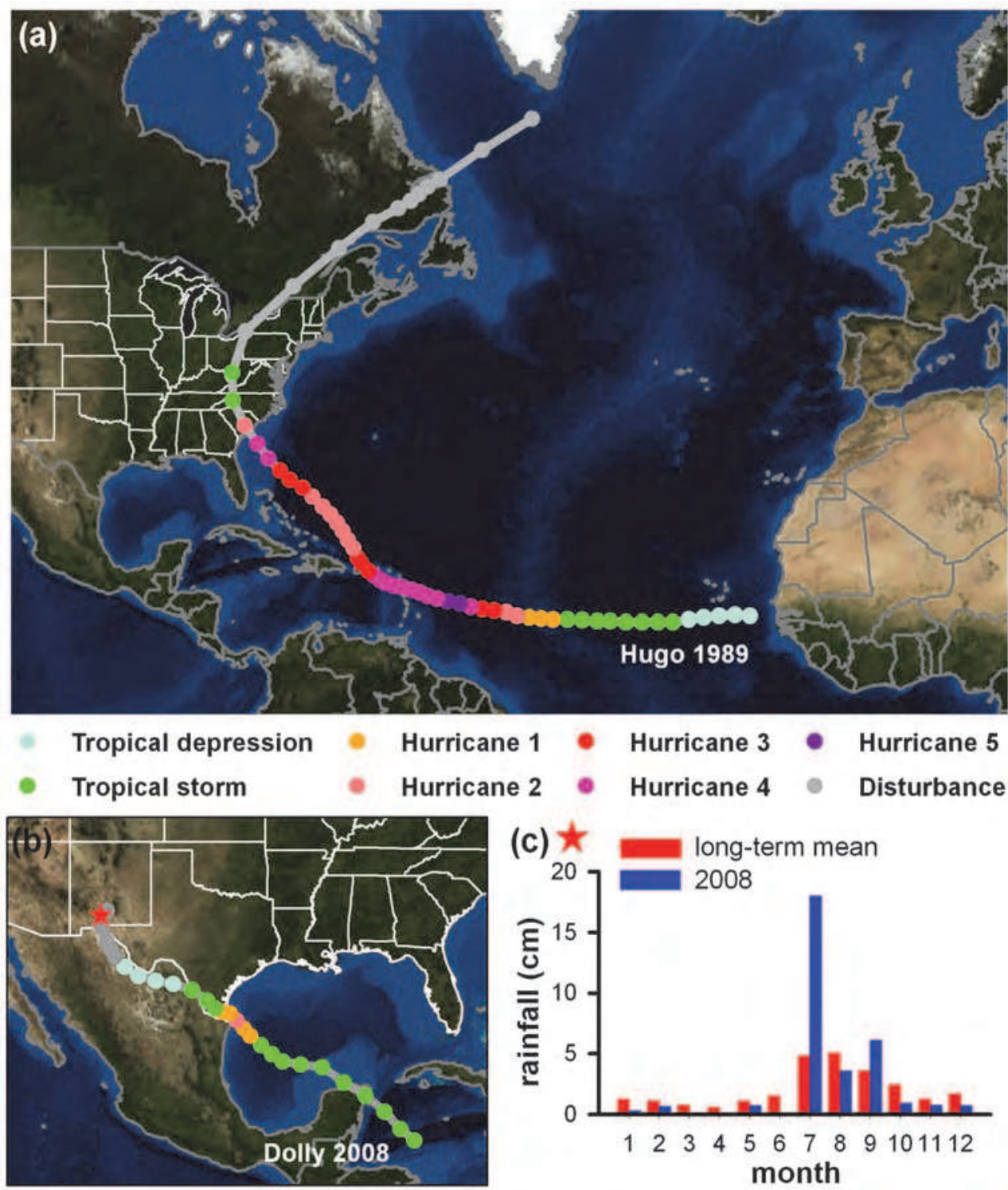

Hurricane 3

Hurricane 5

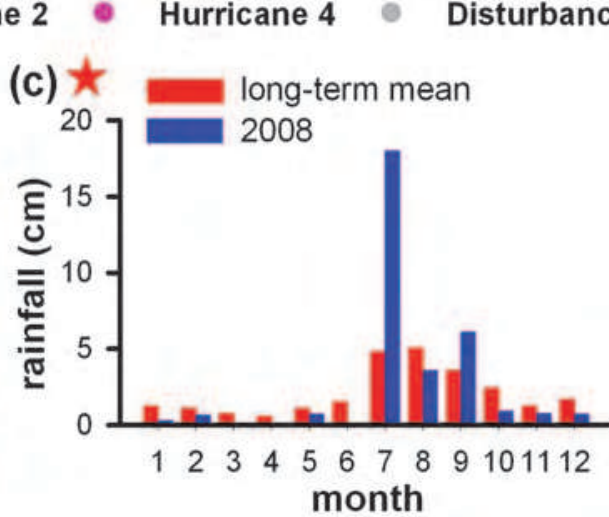

Fig. 9. Hurricanes are one example of an amplification event that starts small and propagates nonlinearly through time and space to influence very large areas that can connect continents on non-intuitive ways. (a) Hurricanes in North America start as thunderstorms in west Africa that move off-shore to create tropical depressions. As the depression builds in size and intensity, a tropical storm results that continues to build until a hurricane develops. Each stage is driven by a different set of linked atmospheric-oceanic processes with thresholds occurring between stages (http://maps.csc.noaa.gov; http://ww2010.atmos/uiuc.edu). (b) Although most hurricanes follow a similar track as 
Hurricane Hugo, in some cases, hurricanes begin in the Gulf of Mexico and strike land in extremely south Texas and move to the northwest before heading east. These hurricanes (e.g., Hurricane Dolly: http://www.hpc.ncep.noaa.gov/) can result in very large amounts of rainfall over short periods of time in locations that are typically very dry. (c) For example, Hurricane Dolly produced $86 \%$ of the total annual rainfall in one month in locations in the Chihuahuan Desert (http:/ / usda-ars.nmsu.edu ). This large pulse of rainfall resulted in a broad-scale perennial grass recruitment event that has persisted to the present (Peters et al., submitted). Infrequent connectivity between locations on different continents may become more common in the future as the intensity of hurricanes increases with climate change, and may overwhelm dynamics driven historically by local rainfall inputs.

\section{Conclusions}

In an era of globalization, it is imperative that ecologists consider the possibility that local inputs are not governing observed dynamics, but rather that the redistribution of materials from adjacent or non-contiguous locations are overwhelming these local effects. This realization will require a "mind shift" away from the traditional approaches of relating ecological dynamics to local drivers, such as precipitation, with high unexplained variation. Conceptualizing ecological systems as inter-connected across many scales in the Earth System is one way to explain this high variation. Three classes of events were described here as ways to accomplish this shift in thinking and application. For example, extremely high precipitation amounts leading to unusual grass recruitment in the Chihuahuan Desert in 2008 resulted from a hurricane in the Gulf of Mexico. Under such a highly connected system, apparent impacts of local climate change will require an examination of drivers in non-contiguous locations across the globe. In this example, factors that influence rainfall in the Gulf of Mexico may be equally important as local drivers to future extreme rainfall events in the Chihuahuan Desert and the American Southwest regions. Future research is needed to identify where, when, and how the different elements of the Earth System are connected. Experimental manipulations across locations and biomes that include transport vectors at multiple scales are critically needed. Simulation models with an explicit consideration of thresholds and cross-scale interactions of the linked land-atmospheresurface water system will be required for prediction. These challenges are large, but the development of cyberinfrastructure software, hardware, and accessibility tools are on the near horizon that will allow global information transfer and use that are needed for synthesis (Carpenter et al., 2009). Ecologists need to be ready (conceptually and quantitatively) to take full advantage of these tools.

\section{Acknowledgements}

Funding support was provided by the National Science Foundation to New Mexico State University as part of the Jornada Basin Long Term Ecological Research Program (DEB0618210). Jin Yao assisted in figure preparation.

\section{Reference}

Albertson, F.W., \& Weaver, J.E. (1942). History of the native vegetation of western Kansas during seven years of continuous drought. Ecological Monographs, 12, 23-51. 
Allen, C.D. (2007). Interactions across spatial scales among forest dieback, fire, and erosion in northern New Mexico landscapes. Ecosystems, 10, 797-808.

Allen, T.F.H., \& Starr, T.B. (1982). Hierarchy theory: perspectives for ecological complexity. University of Chicago Press, Chicago, IL, USA.

Avila, L.A., \& Clark, G.B. Clark. (1989). Atlantic tropical systems of 1988. Monthly Weather Review, 117, 2260-2265.

Bender, E. A., Case, T. J., \& Gilpin, M.E. (1984). Perturbation experiments in community ecology: theory and practice. Ecology, 65, 1-13.

Carpenter, S.R., Armbrust, E.V., Arzberger, P.W., Chapin, F.S. III, Elser, J.J., Hackett, E.J., Ives, A.R., Kareiva, P.M., Leibold, M.A., Lundberg, P., Mangel, M., Merchant, N., Murdoch, W.W., Palmer, M.A., Peters, D.P.C., Pickett, S.T.A., Smith, K.K., Wall, D.H., \& Zimmerman, A.S. (2009). Accelerate synthesis in ecology and environmental sciences. BioScience, 59, 699-701.

Crowl, T.A., Crist, T.O., Parmenter, R.R., Belovsky, G., \& Lugo, A.E. (2008). The spread of invasive species and infectious disease as drivers of ecosystem change. Frontiers in Ecology and the Environment, 6, 238-246.

Dale, V.H., Joyce, L.A., McNulty, S., Neilson, R.P., Ayres, M.P., Flannigan, M.D., Hanson, P.J., Irland, L.C., Lugo, A.E., Peterson, C.J., Simberloff, D., Swanson, F.J., Stocks, B.J., \& Wotton, B.M. (2001). Climate change and forest disturbances. BioScience, 51, 723-734.

Daly, C., Bachelet, D., Lenihan, J.M., Neilson, R.P., Parton, W.J., \& Ojima, D.S. (2000). Dynamic simulation of tree-grass interactions for global change studies. Ecological Applications, 10, 449-469.

Dennis, R., Haeuber, R., Blett, T., Cosby, J., Discoll, C.T., Sickles, J., \& Johnston, J. (2007). Sulfur and nitrogen deposition on ecosystems in the United States. Environmental Management, 2007, 12-17.

Dietz, T., Rosa, E.A., York, R. (2007). Driving the human ecological footprint. Frontiers in Ecology and the Environment, 5, 13-18.

Driscoll, C.T., Whitall, D., Aber, J., Boyer, E., Castro, M., Cronan, C., Goodale, C.L., Groffman, P., Hopkinson, C., Lambert, K., Lawrence, G., \& Ollinger, S. (2003). Nitrogen pollution in the northeastern United States: Sources, effects, and management options. BioScience, 53, 357-374.

Driscoll, C.T., Groffman, P.M., Blair, J.M., Lugo, A.E., Laney, C.M. \& Peters, D.P.C. (2011). Cross-site comparisons of precipitation and surface water chemistry. In: Long-term trends in ecological systems: a basis for understanding responses to global change. Peters, D.P.C., Laney, C.M., Lugo, A.E., Collins, S.L., Driscoll, C.T., Groffman, P.M., Grove, J.M., Knapp, A.K., Kratz, T.K., Ohman, M.D., Waide, R.B., \& Yao, J. (eds). pp. xxxxxx. USDA Agricultural Research Service Publication No. XX. Washington, D.C.

Dunn, G.E. (1940). Cyclogenesis in the tropical Atlantic. Bulletin of the American Meteorological Society, 21, 215-229.

Emanuel, K.A. (2005). Increasing destructiveness of tropical cyclones over the past 30 years. Nature, 436, 686-688.

Fagre, D.B., Charles, C.W., lead authors. (2009). Thresholds of climate change in ecosystems. U.S. Geological Survey, Department of the Interior, Washington, DC. 
Fay, P.A., Kaufman, D.M., Nippert, J.B., Carlisle, J.D., \& Harper, C.W. (2008). Changes in grassland ecosystem function due to extreme rainfall events: implications for responses to climate change. Global Change Biology, 14, 1600-1608.

Fernando, H.J.S. \& McCulley, R. (2005). Coral poaching worsens tsunami destruction in Sri Lanka. Eoc, 86, 301-304.

Field, J.P. Belnap, J., Breshears, D.D., Neff, J.C., Okin, G.S., Whicker, J.J., Painter, T.P., Ravi, S., Reheis, M.C., \& Reynolds, R.L. (2010). The ecology of dust. Frontiers in Ecology and the Environment, 8, 423-430.

Glantz, M.H., Katz, R.W. , \& Nicholls, N. (1991). Teleconnections linking worldwide climate anomalies: scientific basis and societal impact. Cambridge University Press, Cambridge. 534pp.

Goldenberg, S.B., Landsea, C.W., Mestas-Nuñez, A.M., \& Gray, W.M. (2001). The recent increase in Atlantic hurricane activity: causes and implications. Science, 293, 474479 .

Heisler-White, J.L., Blair, J.M., Kelly, E.F., Harmoney, K., \& Knapp, A.K. (2009). Contingent productivity responses to more extreme rainfall regimes across a grassland biome. Global Change Biology, 15, 2894-2904.

Hobbs, R.J., Arico, S., Aronson, J., Baron, J.S., Bridgewater, P., Cramer, V.A., Epstein, P.R., Ewel, J.J., Klink, C.A., Lugo, A.E., Norton, D., Ojima, D., Richardson, D.M., Sanderson, E.W., Valladares, F., Vila, M., Zamora, R., \& Zovel, M. (2006). Novel ecosystems: theoretical and management aspects of the new ecological world order. Global Ecology and Biogeography, 15, 1-7.

Hopkinson, C.S., Lugo, A.E., Alber, M., Covich, A.P., \& Van Bloem, S.J. (2008). Forecasting effects of sea-level rise and windstorms on coastal and inland ecosystems. Frontiers in Ecology and the Environment, 6, 255-263.

IPCC. (2007). Climate Change 2007: The Physical Science Basis. In: Contribution of Working Group I to the Fourth Assessment Report of the Intergovernmental Panel on Climate Change. Solomon, S., Qin, D., Manning, M., Chen, Z., Marquis, M., Avery, K.B., Tignor, M., \& Miller, H.L. (eds.) Cambridge University Press, Cambridge, United Kingdom and New York, NY, USA.

Ivanov, V.Y., Bras, R.L., \& Vivoni, E.R. (2008). Vegetation-hydrology dynamics in complex terrain of semiarid areas: 1. A mechanistic approach to modeling dynamic feedbacks. Water Resources Research, 44, W03429, doi:10.1029/2006/WR005588.

Jaffe, D., McKendry, I., Anderson, T., \& Price, H. (2003). Six “new" episodes of trans-Pacific transport of air pollutants. Atmospheric Environment, 37, 391-404.

Jones, J.A., \& Post, D.A. (2004). Seasonal and successional streamflow response to forest cutting and regrowth in the northwest and eastern United States. Water Resources Research, 40, W05203, doi:10.1029/2003WR002952.

Kitzberger, T., Brown, P.M., Heyerdahl, E.K., Swetnam, T.W., \& Veblen, T.J. (2007). Contingent Pacific-Atlantic Ocean influence on multicentury wildfire synchrony over western North America. Proceedings of the National Academy of Sciences, 104, 543-548.

Landsea, C.W. (1993). A climatology of intense (or major) Atlantic hurricanes. Monthly Weather Review, 121, 1703-1713. 
Landsea, C.W., Bell, G.D., Gray, W.M., \& Goldenberg, S.B. (1998). The extremely active 1995 Atlantic hurricane season: environmental conditions and verification of seasonal forecasts. Monthly Weather Review, 126, 1174-1193.

Li, J.R., Okin, G.S., Alvarez, L.J., \& Epstein, H.E. (2009a). Sediment deposition and soil nutrient heterogeneity in two desert grassland ecosystems, southern New Mexico, southern New Mexico. Plant and Soil, 319(1-2), 67-84.

Li, J.R., Okin, G.S., \& Epstein, H.E. (2009b). Effects of enhanced wind erosion on surface soil texture and characteristics of windblown sediments. Journal of Geophysical ResearchBiogeosciences, 114, DOI:10.1029/2008JG000903.

Luck, M.A, Jenerette, G.D., Wu, J., \& Grimm, N.B. (2001). The urban funnel model and spatially heterogeneous ecological footprint. Ecosystems, 4, 782-796.

Lugo, A.E., Swanson, F.J., Gonzalez, O.R., Adams, M.B., Palik, B., Thill, R.E., Brockway, D.G., Kern, C., Woodsmith, R., \& Musselman, R. (2006). Long- term research at the USDA Forest Service's experimental forests and ranges. BioScience, 56, 39-48.

Marshall, J.D., Blair, J.M., Peters, D.P.C., Okin, G.S., Rango, A., \& Williams, M. (2008). Predicting and understanding ecosystem responses to climate change at continental scales. Frontiers in Ecology and the Environment, 6, 273-280.

Merrifield, M.A., Firing, Y.L., Aarup, T., Agricole, W., Brundit, G., Chang-Seng, D., Farre, R., Kilonsky, B., Knight, W., Kong, L., Magori, C., Manurung, P., McCreery, C., Mitchell, W., Pillary, S., Scindele, F., Shillington, F., Testut, L., Wijeratne, E.M.S., Caldwell, P., Jardin, J., Nakahara, S., Porter, F-Y., Turetsky, N. (2005). Tide gauge observations of the Indian Ocean tsunami, December 26, 2004. Geophysical Research Letters, 32, L09603, doi:10.1029/2005GL022610.

McConnell, J.R., Aristarain, A.J., Banta, J.R., Edwards, P.R., \& Simones, J.C. (2007). 20thCentury doubling in dust archived in an Antarctic Peninsula ice core parallels climate change and desertification in South America. Proceedings in the National Academy of Sciences USA, 104, 5743-5748.

Millenium Ecosystem Assessment (MEA). (2005). Ecosystems and human well-being: synthesis. Island Press, Washington, D.C.

Moran M.S., Peters, D.P.C., McClaran, M., Nichols, M.H., \& Adams, M. (2008). Long-term data collection at USDA experimental sites for studies of ecohydrology. Ecohydrology, 1, 377-393.

Mulholland, P. J., Helton, A.M., Poole, G.C., Hall, R.O. Jr., Hamilton, S.K., Peterson, B.J., Tank, J.L., Ashkenas, L.R., Cooper, L.W., Dahm, C.N., Dodds, W.K., Findlay, S., Gregory, S.V., Grimm, N.B., Johnson, S.L., McDowell, W.H., Meyer, J.L., Valett, J,M., Webster, J.R., Arango, C., Beaulieu, J.J., Bernot, M.J., Burgin, A.J., Crenshaw, C., Johnson, L., Merriam, J., Niederlehner, B.R., O'Brien, J.M., Potter, J.D., Sheibley, R.W., Sobota, D.J., \& Thomas, S.M. (2008). Stream denitrification across biomes and its response to anthropogenic nitrate loading. Nature, 452, 202-205.

Neff, J.C., Ballantyne, A.P., Farmer, G.L., Mahowald, N.M., Conroy, J.L., Landry, C.C., Overpeck, J.T., Painter, T.H., Lawrence, C.R., \& Reynolds, R.L. (2008). Nature Geoscience, 1, 189-195.

O'Brien, J.M., Dodds, W.K., Wilson, K.C., Murdock, J.N., \& Eichmiller, J. (2007). The saturation of $\mathrm{N}$ cycling in Central Plains streams: $15 \mathrm{~N}$ experiments across a broad gradient of nitrate concentrations. Biogeochemistry, 84, 31-49. 
Okin, G.S. (2008). A new model of wind erosion in the presence of vegetation. Journal of Geophysical Research-Earth Surface, 113, F02S10, doi:10.1029/2007JF000758.

Okin, G.S., Parson, A.J., Wainwright J., Herrick, J.E., Bestelmeyer, B.T., Peters, D.P.C., \& Fredrickson, E.L. (2009). Do changes in connectivity explain desertification? BioScience, 59, 237-244.

Palmer, W.C. (1965) Meteorological Drought. Research Paper No. 45, Dept. of Commerce, Washington, D.C.

Perrings, C., Mooney, H., \& Williamson, M. (2010). Bioinvasions and globalization: ecology, economics, management, and policy. Oxford University Press, Oxford.

Peters, D.P.C. (2010). Accessible ecology: synthesis of the long, deep, and broad. Trends in Ecology and Evolution, 25, 592-601.

Peters, D.P.C., Bestelmeyer, B.T., Herrick, J.E., Monger, H.C., Fredrickson, E., \& Havstad, K.M. (2006a). Disentangling complex landscapes: new insights to forecasting arid and semiarid system dynamics. BioScience, 56, 491-501.

Peters, D.P.C., Groffman, P.M., Nadelhoffer, K.J., Grimm, N.B., Collins, S.L., Michener, W.K., \& Huston, M.A. (2008). Living in an increasingly connected world: a framework for continental-scale environmental science. Frontiers in Ecology and the Environment, 5, 229-237.

Peters, D.P.C., Laney, C.M., Lugo, A.E., Collins, S.L., Driscoll, C.T., Groffman, P.M., Grove, J.M., Knapp, A.K., Kratz, T.K., Ohman, M.D., Waide, R.B., \& Yao, J. (2011). Longterm trends in ecological systems: a basis for understanding responses to global change. USDA Agricultural Research Service Publication No. XX. Washington, D.C.

Peters, D.P.C., Pielke, R.A. Sr, Bestelmeyer, B.T., Allen, C.D., Munson-McGee, S., \& Havstad, K.M. (2004a). Cross-scale interactions, nonlinearities, and forecasting catastrophic events. Proceedings of the National Academy of Sciences USA, 101, 15130-15135.

Peters, D.P.C., Pielke, R.A. Sr, Bestelmeyer, B.T., Allen, C.D., Munson-McGee, S., \& Havstad, K.M. 2006b. Spatial nonlinearities in the Earth System. In: Terrestrial ecosystems in a changing world, Canadell, J., Pataki, D., \& Pitelka, L., eds, pp. 165-173, Springer, Berlin.

Peters, D.P.C., Urban, D.L., Gardner, R.H., Breshears, D.D., \& Herrick, J.E (2004b0. Strategies for ecological extrapolation. Oikos, 106, 627-636.

Peters, D.P.C., Yao, J., Sala, O.E., Anderson, J. (submitted). Directional climate change and potential reversal of desertification in arid ecosystems. Global Change Biology.

Reichman, O.J., Jones, M.B., \& Schildhauer, M.P. (2011). Challenges and opportunities of open data in ecology. Science, 331, 703-705.

Rial, J.A., Pielke, R.A. Sr, Beniston, M., Claussen, M., Canadell, J., Cox, P., Held, H., de Noblet-Ducoudé, N., Prinn, R., Reynolds, J.F., \& Salas, J.D. (2004). Nonlinearities, feedbacks, and critical thresholds within the Earth's climate system. Climatic Change, 65, 11-38.

Tanaka, T.Y. \& Chiba, M. (2006). A numerical study of the contributions of dust source regions to the global dust budget. Global Planetary Change, 52, 88-104.

Trenberth, K.E. (2005). Uncertainty In hurricanes and global warming. Science, 308, 17531754.

Weaver, J.E., \& Albertson, F.W. (1940). Deterioration of Midwestern ranges. Ecology, 21, 216236. 
Williamson, C.E., Dodds, W., Kratz, T.K., \& Palmer, M.A. (2008). Lakes and streams as sentinels of environmental change in terrestrial and atmospheric processes. Frontiers in Ecology and the Environment, 5, 247-254.

Yates,T.L., Mills, J.N., Parmenter, C.A., Ksiazek, T.G., Parmenter, R.R., Vande Castle, J.R., Calisher, C.H., Nichol, S.T., Abbott, K.D., Young, J.C., Morrison, M.L., Beaty, B.J., Dunnum, J.L., Baker, R.J., Salazar-Bravo, J., \& Peters, C.J. (2002). The ecology and evolutionary history of an emergent disease: hantavirus pulmonary syndrome. BioScience, 52, 989-998.Dennis, R., Haeuber, R., Blett, T., Cosby, J., Discoll, C.T., Sickles, J., \& Johnston, J. (2007). Sulfur and nitrogen deposition on ecosystems in the United States. Environmental Management, 2007, 12-17.

Dietz, T., Rosa, E.A., York, R. (2007). Driving the human ecological footprint. Frontiers in Ecology and the Environment, 5, 13-18.

Driscoll, C.T., Whitall, D., Aber, J., Boyer, E., Castro, M., Cronan, C., Goodale, C.L., Groffman, P., Hopkinson, C., Lambert, K., Lawrence, G., \& Ollinger, S. (2003). Nitrogen pollution in the northeastern United States: Sources, effects, and management options. BioScience, 53, 357-374.

Driscoll, C.T., Groffman, P.M., Blair, J.M., Lugo, A.E., Laney, C.M. \& Peters, D.P.C. (2011). Cross-site comparisons of precipitation and surface water chemistry. In: Long-term trends in ecological systems: a basis for understanding responses to global change. Peters, D.P.C., Laney, C.M., Lugo, A.E., Collins, S.L., Driscoll, C.T., Groffman, P.M., Grove, J.M., Knapp, A.K., Kratz, T.K., Ohman, M.D., Waide, R.B., \& Yao, J. (eds). pp. xxxxxx. USDA Agricultural Research Service Publication No. XX. Washington, D.C.

Dunn, G.E. (1940). Cyclogenesis in the tropical Atlantic. Bulletin of the American Meteorological Society, 21, 215-229.

Emanuel, K.A. (2005). Increasing destructiveness of tropical cyclones over the past 30 years. Nature, 436, 686-688.

Fagre, D.B., Charles, C.W., lead authors. (2009). Thresholds of climate change in ecosystems. U.S. Geological Survey, Department of the Interior, Washington, DC.

Fay, P.A., Kaufman, D.M., Nippert, J.B., Carlisle, J.D., \& Harper, C.W. (2008). Changes in grassland ecosystem function due to extreme rainfall events: implications for responses to climate change. Global Change Biology, 14, 1600-1608.

Fernando, H.J.S. \& McCulley, R. (2005). Coral poaching worsens tsunami destruction in Sri Lanka. Eoc, 86, 301-304.

Field, J.P. Belnap, J., Breshears, D.D., Neff, J.C., Okin, G.S., Whicker, J.J., Painter, T.P., Ravi, S., Reheis, M.C., \& Reynolds, R.L. (2010). The ecology of dust. Frontiers in Ecology and the Environment, 8, 423-430.

Glantz, M.H., Katz, R.W. , \& Nicholls, N. (1991). Teleconnections linking worldwide climate anomalies: scientific basis and societal impact. Cambridge University Press, Cambridge. 534pp.

Goldenberg, S.B., Landsea, C.W., Mestas-Nuñez, A.M., \& Gray, W.M. (2001). The recent increase in Atlantic hurricane activity: causes and implications. Science, 293, 474479 .

Heisler-White, J.L., Blair, J.M., Kelly, E.F., Harmoney, K., \& Knapp, A.K. (2009). Contingent productivity responses to more extreme rainfall regimes across a grassland biome. Global Change Biology, 15, 2894-2904. 
Hobbs, R.J., Arico, S., Aronson, J., Baron, J.S., Bridgewater, P., Cramer, V.A., Epstein, P.R., Ewel, J.J., Klink, C.A., Lugo, A.E., Norton, D., Ojima, D., Richardson, D.M., Sanderson, E.W., Valladares, F., Vila, M., Zamora, R., \& Zovel, M. (2006). Novel ecosystems: theoretical and management aspects of the new ecological world order. Global Ecology and Biogeography, 15, 1-7.

Hopkinson, C.S., Lugo, A.E., Alber, M., Covich, A.P., \& Van Bloem, S.J. (2008). Forecasting effects of sea-level rise and windstorms on coastal and inland ecosystems. Frontiers in Ecology and the Environment, 6, 255-263.

IPCC. (2007). Climate Change 2007: The Physical Science Basis. In: Contribution of Working Group I to the Fourth Assessment Report of the Intergovernmental Panel on Climate Change. Solomon, S., Qin, D., Manning, M., Chen, Z., Marquis, M., Avery, K.B., Tignor, M., \& Miller, H.L. (eds.) Cambridge University Press, Cambridge, United Kingdom and New York, NY, USA.

Ivanov, V.Y., Bras, R.L., \& Vivoni, E.R. (2008). Vegetation-hydrology dynamics in complex terrain of semiarid areas: 1. A mechanistic approach to modeling dynamic feedbacks. Water Resources Research, 44, W03429, doi:10.1029/2006/WR005588.

Jaffe, D., McKendry, I., Anderson, T., \& Price, H. (2003). Six “new" episodes of trans-Pacific transport of air pollutants. Atmospheric Environment, 37, 391-404.

Jones, J.A., \& Post, D.A. (2004). Seasonal and successional streamflow response to forest cutting and regrowth in the northwest and eastern United States. Water Resources Research, 40, W05203, doi:10.1029/2003WR002952.

Kitzberger, T., Brown, P.M., Heyerdahl, E.K., Swetnam, T.W., \& Veblen, T.J. (2007). Contingent Pacific-Atlantic Ocean influence on multicentury wildfire synchrony over western North America. Proceedings of the National Academy of Sciences, 104, 543-548.

Landsea, C.W. (1993). A climatology of intense (or major) Atlantic hurricanes. Monthly Weather Review, 121, 1703-1713.

Landsea, C.W., Bell, G.D., Gray, W.M., \& Goldenberg, S.B. (1998). The extremely active 1995 Atlantic hurricane season: environmental conditions and verification of seasonal forecasts. Monthly Weather Review, 126, 1174-1193.

Li, J.R., Okin, G.S., Alvarez, L.J., \& Epstein, H.E. (2009a). Sediment deposition and soil nutrient heterogeneity in two desert grassland ecosystems, southern New Mexico, southern New Mexico. Plant and Soil, 319(1-2), 67-84.

Li, J.R., Okin, G.S., \& Epstein, H.E. (2009b). Effects of enhanced wind erosion on surface soil texture and characteristics of windblown sediments. Journal of Geophysical ResearchBiogeosciences, 114, DOI:10.1029/2008JG000903.

Luck, M.A, Jenerette, G.D., Wu, J., \& Grimm, N.B. (2001). The urban funnel model and spatially heterogeneous ecological footprint. Ecosystems, 4, 782-796.

Lugo, A.E., Swanson, F.J., Gonzalez, O.R., Adams, M.B., Palik, B., Thill, R.E., Brockway, D.G., Kern, C., Woodsmith, R., \& Musselman, R. (2006). Long- term research at the USDA Forest Service's experimental forests and ranges. BioScience, 56, 39-48.

Marshall, J.D., Blair, J.M., Peters, D.P.C., Okin, G.S., Rango, A., \& Williams, M. (2008). Predicting and understanding ecosystem responses to climate change at continental scales. Frontiers in Ecology and the Environment, 6, 273-280.

Merrifield, M.A., Firing, Y.L., Aarup, T., Agricole, W., Brundit, G., Chang-Seng, D., Farre, R., Kilonsky, B., Knight, W., Kong, L., Magori, C., Manurung, P., McCreery, C., 
Mitchell, W., Pillary, S., Scindele, F., Shillington, F., Testut, L., Wijeratne, E.M.S., Caldwell, P., Jardin, J., Nakahara, S., Porter, F-Y., Turetsky, N. (2005). Tide gauge observations of the Indian Ocean tsunami, December 26, 2004. Geophysical Research Letters, 32, L09603, doi:10.1029/2005GL022610.

McConnell, J.R., Aristarain, A.J., Banta, J.R., Edwards, P.R., \& Simones, J.C. (2007). 20thCentury doubling in dust archived in an Antarctic Peninsula ice core parallels climate change and desertification in South America. Proceedings in the National Academy of Sciences USA, 104, 5743-5748.

Millenium Ecosystem Assessment (MEA). (2005). Ecosystems and human well-being: synthesis. Island Press, Washington, D.C.

Moran M.S., Peters, D.P.C., McClaran, M., Nichols, M.H., \& Adams, M. (2008). Long-term data collection at USDA experimental sites for studies of ecohydrology. Ecohydrology, 1, 377-393.

Mulholland, P. J., Helton, A.M., Poole, G.C., Hall, R.O. Jr., Hamilton, S.K., Peterson, B.J., Tank, J.L., Ashkenas, L.R., Cooper, L.W., Dahm, C.N., Dodds, W.K., Findlay, S., Gregory, S.V., Grimm, N.B., Johnson, S.L., McDowell, W.H., Meyer, J.L., Valett, J,M., Webster, J.R., Arango, C., Beaulieu, J.J., Bernot, M.J., Burgin, A.J., Crenshaw, C., Johnson, L., Merriam, J., Niederlehner, B.R., O'Brien, J.M., Potter, J.D., Sheibley, R.W., Sobota, D.J., \& Thomas, S.M. (2008). Stream denitrification across biomes and its response to anthropogenic nitrate loading. Nature, 452, 202-205.

Neff, J.C., Ballantyne, A.P., Farmer, G.L., Mahowald, N.M., Conroy, J.L., Landry, C.C., Overpeck, J.T., Painter, T.H., Lawrence, C.R., \& Reynolds, R.L. (2008). Nature Geoscience, 1, 189-195.

O'Brien, J.M., Dodds, W.K., Wilson, K.C., Murdock, J.N., \& Eichmiller, J. (2007). The saturation of $\mathrm{N}$ cycling in Central Plains streams: $15 \mathrm{~N}$ experiments across a broad gradient of nitrate concentrations. Biogeochemistry, 84, 31-49.

Okin, G.S. (2008). A new model of wind erosion in the presence of vegetation. Journal of Geophysical Research-Earth Surface, 113, F02S10, doi:10.1029/2007JF000758.

Okin, G.S., Parson, A.J., Wainwright J., Herrick, J.E., Bestelmeyer, B.T., Peters, D.P.C., \& Fredrickson, E.L. (2009). Do changes in connectivity explain desertification? BioScience, 59, 237-244.

Palmer, W.C. (1965) Meteorological Drought. Research Paper No. 45, Dept. of Commerce, Washington, D.C.

Perrings, C., Mooney, H., \& Williamson, M. (2010). Bioinvasions and globalization: ecology, economics, management, and policy. Oxford University Press, Oxford.

Peters, D.P.C. (2010). Accessible ecology: synthesis of the long, deep, and broad. Trends in Ecology and Evolution, 25, 592-601.

Peters, D.P.C., Bestelmeyer, B.T., Herrick, J.E., Monger, H.C., Fredrickson, E., \& Havstad, K.M. (2006a). Disentangling complex landscapes: new insights to forecasting arid and semiarid system dynamics. BioScience, 56, 491-501.

Peters, D.P.C., Groffman, P.M., Nadelhoffer, K.J., Grimm, N.B., Collins, S.L., Michener, W.K., \& Huston, M.A. (2008). Living in an increasingly connected world: a framework for continental-scale environmental science. Frontiers in Ecology and the Environment, 5, 229-237.

Peters, D.P.C., Laney, C.M., Lugo, A.E., Collins, S.L., Driscoll, C.T., Groffman, P.M., Grove, J.M., Knapp, A.K., Kratz, T.K., Ohman, M.D., Waide, R.B., \& Yao, J. (2011). Long- 
term trends in ecological systems: a basis for understanding responses to global change. USDA Agricultural Research Service Publication No. XX. Washington, D.C.

Peters, D.P.C., Pielke, R.A. Sr, Bestelmeyer, B.T., Allen, C.D., Munson-McGee, S., \& Havstad, K.M. (2004a). Cross-scale interactions, nonlinearities, and forecasting catastrophic events. Proceedings of the National Academy of Sciences USA, 101, 15130-15135.

Peters, D.P.C., Pielke, R.A. Sr, Bestelmeyer, B.T., Allen, C.D., Munson-McGee, S., \& Havstad, K.M. 2006b. Spatial nonlinearities in the Earth System. In: Terrestrial ecosystems in a changing world, Canadell, J., Pataki, D., \& Pitelka, L., eds, pp. 165-173, Springer, Berlin.

Peters, D.P.C., Urban, D.L., Gardner, R.H., Breshears, D.D., \& Herrick, J.E (2004b0. Strategies for ecological extrapolation. Oikos, 106, 627-636.

Peters, D.P.C., Yao, J., Sala, O.E., Anderson, J. (submitted). Directional climate change and potential reversal of desertification in arid ecosystems. Global Change Biology.

Reichman, O.J., Jones, M.B., \& Schildhauer, M.P. (2011). Challenges and opportunities of open data in ecology. Science, 331, 703-705.

Rial, J.A., Pielke, R.A. Sr, Beniston, M., Claussen, M., Canadell, J., Cox, P., Held, H., de Noblet-Ducoudé, N., Prinn, R., Reynolds, J.F., \& Salas, J.D. (2004). Nonlinearities, feedbacks, and critical thresholds within the Earth's climate system. Climatic Change, 65, 11-38.

Tanaka, T.Y. \& Chiba, M. (2006). A numerical study of the contributions of dust source regions to the global dust budget. Global Planetary Change, 52, 88-104.

Trenberth, K.E. (2005). Uncertainty In hurricanes and global warming. Science, 308, 17531754.

Weaver, J.E., \& Albertson, F.W. (1940). Deterioration of Midwestern ranges. Ecology, 21, 216236.

Williamson, C.E., Dodds, W., Kratz, T.K., \& Palmer, M.A. (2008). Lakes and streams as sentinels of environmental change in terrestrial and atmospheric processes. Frontiers in Ecology and the Environment, 5, 247-254.

Yates,T.L., Mills, J.N., Parmenter, C.A., Ksiazek, T.G., Parmenter, R.R., Vande Castle, J.R., Calisher, C.H., Nichol, S.T., Abbott, K.D., Young, J.C., Morrison, M.L., Beaty, B.J., Dunnum, J.L., Baker, R.J., Salazar-Bravo, J., \& Peters, C.J. (2002). The ecology and evolutionary history of an emergent disease: hantavirus pulmonary syndrome. BioScience, 52, 989-998. 


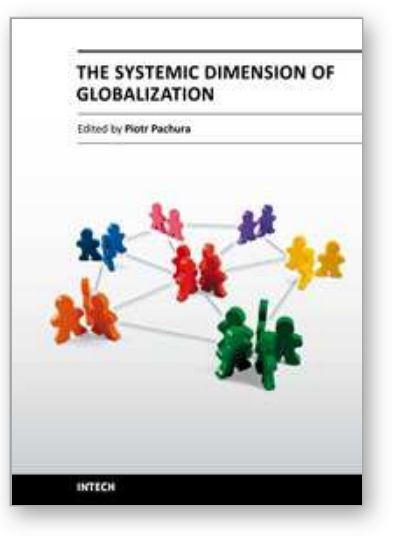

\author{
The Systemic Dimension of Globalization \\ Edited by Prof. Piotr Pachura
}

ISBN 978-953-307-384-2

Hard cover, 288 pages

Publisher InTech

Published online 01, August, 2011

Published in print edition August, 2011

Today science is moving in the direction of synthesis of the achievements of various academic disciplines. The idea to prepare and present to the international academic milieu, a multidimensional approach to globalization phenomenon is an ambitious undertaking. The book The Systemic Dimension of Globalization consists of 14 chapters divided into three sections: Globalization and Complex Systems; Globalization and Social Systems; Globalization and Natural Systems. The Authors of respective chapters represent a great diversity of disciplines and methodological approaches as well as a variety of academic culture. This is the value of this book and this merit will be appreciated by a global community of scholars.

\title{
How to reference
}

In order to correctly reference this scholarly work, feel free to copy and paste the following:

Debra P.C. Peters (2011). Globalization: Ecological Consequences of Global-Scale Connectivity in People, Resources, and Information, The Systemic Dimension of Globalization, Prof. Piotr Pachura (Ed.), ISBN: 978953-307-384-2, InTech, Available from: http://www.intechopen.com/books/the-systemic-dimension-ofglobalization/globalization-ecological-consequences-of-global-scale-connectivity-in-people-resources-andinformati

\section{INTECH}

open science | open minds

\author{
InTech Europe \\ University Campus STeP Ri \\ Slavka Krautzeka 83/A \\ 51000 Rijeka, Croatia \\ Phone: +385 (51) 770447 \\ Fax: +385 (51) 686166 \\ www.intechopen.com
}

\author{
InTech China \\ Unit 405, Office Block, Hotel Equatorial Shanghai \\ No.65, Yan An Road (West), Shanghai, 200040, China \\ 中国上海市延安西路65号上海国际贵都大饭店办公楼405单元 \\ Phone: +86-21-62489820 \\ Fax: +86-21-62489821
}


(C) 2011 The Author(s). Licensee IntechOpen. This chapter is distributed under the terms of the Creative Commons Attribution-NonCommercialShareAlike-3.0 License, which permits use, distribution and reproduction for non-commercial purposes, provided the original is properly cited and derivative works building on this content are distributed under the same license. 